Article

\title{
Assessments of Organic Carbon Stabilization Using the Spectroscopic Characteristics of Humic Acids Separated from Soils of the Lena River Delta
}

\author{
Vyacheslav Polyakov 1,2,*(D) and Evgeny Abakumov ${ }^{2}$ (D) \\ 1 Department of Applied Ecology, Faculty of Biology, St. Petersburg State University, 16th Liniya V.O., 29, \\ 199178 St. Petersburg, Russia \\ 2 Arctic and Antarctic Research Institute, Beringa 38, 199397 St. Petersburg, Russia; st049428@student.spbu.ru \\ * Correspondence: slavon6985@gmail.com; Tel.: +7-953-172-4997
}

Citation: Polyakov, V.; Abakumov, E. Assessments of Organic Carbon Stabilization Using the Spectroscopic Characteristics of Humic Acids Separated from Soils of the Lena River Delta. Separations 2021, 8, 87. https://doi.org/10.3390/ separations 8060087

Academic Editor: Ronald Beckett

Received: 30 April 2021

Accepted: 16 June 2021

Published: 20 June 2021

Publisher's Note: MDPI stays neutral with regard to jurisdictional claims in published maps and institutional affiliations.

Copyright: (C) 2021 by the authors. Licensee MDPI, Basel, Switzerland. This article is an open access article distributed under the terms and conditions of the Creative Commons Attribution (CC BY) license (https:/ / creativecommons.org/licenses/by/ $4.0 /)$.

\begin{abstract}
In the Arctic zone, where up to $1024 \times 1013 \mathrm{~kg}$ of organic matter is stored in permafrostaffected soils, soil organic matter consists of about $50 \%$ humic substances. Based on the analysis of the molecular composition of humic acids, we assessed the processes of accumulation of the key structural fragments, their transformations and the stabilization rates of carbon pools in soils in general. The landscape of the Lena River delta is the largest storage of stabilized organic matter in the Arctic. There is active accumulation and deposition of a significant amount of soil organic carbon from terrestrial ecosystems in a permafrost state. Under ongoing climate change, carbon emission fluxes into the atmosphere are estimated to be higher than the sequestration and storing of carbon compounds. Thus, investigation of soil organic matter stabilization mechanisms and rates is quite an urgent topic regarding polar soils. For study of molecular elemental composition, humic acids were separated from the soils of the Lena River delta. Key structural fragments of humic matter were identified and quantified by $\mathrm{CP} / \mathrm{MAS}{ }^{13} \mathrm{C}$ NMR spectroscopy: carboxyl (-COOR); carbonyl $(-\mathrm{C}=\mathrm{O}) ; \mathrm{CH}^{3-} ; \mathrm{CH}^{2-} ; \mathrm{CH}$-aliphatic; $-\mathrm{C}-\mathrm{OR}$ alcohols, esters and carbohydrates; and the phenolic $(\mathrm{Ar}-\mathrm{OH})$, quinone $(\mathrm{Ar}=\mathrm{O})$ and aromatic $(\mathrm{Ar}-)$ groups as benchmark Cryosols of the Lena delta river terrestrial ecosystem. Under the conditions of thermodynamic evolutionary selection, during the change between the dry and wet seasons, up to $41 \%$ of aromatic and carboxyl fragments accumulated in humic acids. Data obtained showed that three main groups of carbon played the most important role in soil organic matter stabilization, namely $\mathrm{C}, \mathrm{H}$-alkyls $\left(\left(\mathrm{CH}_{2}\right) \mathrm{n} / \mathrm{CH} / \mathrm{C}\right.$ and $\left.\mathrm{CH}_{3}\right)$, aromatic compounds (C-C/C-H, C-O) and an OCH group (OCH/OCq). The variations of these carbon species' content in separated humics, with special reference to soil-permafrost organic profiles' recalcitrance in the current environment, is discussed.
\end{abstract}

Keywords: soil organic matter; ${ }^{13} \mathrm{C}-\mathrm{NMR}$ spectroscopy; carbon stabilization; Arctic; Cryosol

\section{Introduction}

Soil organic matter (SOM) is a product that accumulates in soil after the partial decomposition of various types of materials derived from microorganisms and plant residues. It constitutes a key element of the global carbon cycle in the atmosphere, vegetation, soil, rivers and oceans [1-4]. Soil organic matter supports key functions of soil and ecosystem services, as it is critical for stabilizing soil structure, retaining and releasing plant nutrients and allowing water to penetrate and be stored in the soil. Soils provide a wide range of ecosystem services (benefits) for human beings. These include water purification and pollutant reduction, climate regulation, nutrient cycling, providing a habitat for various living organisms, being a source of medicinal substances and building materials as well as a basis for infrastructure, and also participating in the sequestration of organic carbon in soil [1]. The most important ecosystem service of the soils of the Arctic belt is the sequestration 
and deposition of SOM within the permafrost. Nowadays, up to $496 \times 10^{13} \mathrm{~kg}$ of SOM are buried in soil in a permafrost state [5,6].

Under the process of climate change, the emission of carbon into the atmosphere can be greater than its sequestration in the soil and permafrost. This could affect the global carbon cycle and accelerate climate change on the planet. Ecosystems with the highest SOM content (meadows, swamps, and permafrost) can make the greatest contributions to climate change. Therefore, to assess the interactions of the biogeochemical carbon cycle with climate, it is important to characterize the areas affected by permafrost as well as the soils' organic carbon stocks and the rate of the soils' transformation. An important direction in the study of the transformation of SOM is the mechanism of stabilization of organic matter; its resistance to biodegradation by soil microorganisms, plants and fungi; and its chemical decomposition [7]. The permafrost zone covers an area of more than 8.6 million $\mathrm{km}^{2}$, which is about $27 \%$ of the total land area above $50^{\circ} \mathrm{N}$. It accumulates a huge amount of organic carbon, and therefore it is considered one of the most important elements of the cryosphere. There, carbon accumulates in soils in huge amounts due to low temperatures, which lead to slow degradation of SOM [7-11]. During the transformation of SOM, greenhouse gases (carbon dioxide and methane) are emitted into the atmosphere. If this happens too quickly, soils can contribute to the climate crisis on our planet. On the other hand, many soils have the potential to increase SOM stocks, thus mitigating climate change by reducing $\mathrm{CO}_{2}$ emissions $[10,12,13]$.

To study the molecular composition of SOM, the analysis of humic acids (HAs), which are formed in soils during the humification of organic residues, has been used. HAs are heterogeneous systems of different (high and low) molecular weights; they are condensed compounds formed as a result of the decomposition of plant and animal remains in terrestrial and aquatic ecosystems [14,15].The question of the structure of HAs still relevant based on the work carried out in the gel chromatography by Piccolo et al. [16]; it was concluded that the HAs were a supramolecular system; they were a set of molecules with relatively low molecular weight (up to several hundred D) combined into a kind of micelle-like structure of hydrogen and hydrophobic bonds. However, this technique allowed us the right to doubt the correctness of the conclusions. According to the work of Perminova [17], the use of a strong mineral acid set to $\mathrm{pH} 2$ in a HA solution changed its ionic strength by only $0.026 \mathrm{M}$; when using a weak organic acid (acetic acid), the content of substances in the system increased by $4.3 \mathrm{M}$. Moreover, data have been given on the existence of macromolecules, which are transformed biomolecules (derivatives of lipids, lignin, carbohydrates and proteins), in the composition of HAs, which does not contradict the "macromolecular model". Thus, modern data on the structure of HAs indicate that it is rather a "molecular ensemble" of macromolecules in which molecules with different molecular weights are present $[14,15]$.

Climatic parameters, precursors of humification and local position in the landscape determine the diversity of the composition and properties of HAs [9,18-22]. Various methods are used to study the HAs in soil organic matter. There are also many methods for determining the composition of HAs. Fourier transform infrared spectroscopy, ultraviolet and visible spectroscopy, cross polarization, magic angle rotation, molecular fluorescence spectroscopy and electron paramagnetic resonance spectroscopy are all useful and often used in SOM studies [23,24].

The method of electron paramagnetic resonance (EPR) is used to determine the structure of SOM, which consists of free radicals. The free radicals participate in the process of polymerization humus formation, and free radical activity is a fundamental property. In a number of works, a correlation between the content of free radicals and the degree of humification was noted. Thus, the thesis was put forward that the condensation of HA molecules led to the formation of polycondensed systems that were biochemically resistant to biodegradation. This method was highly sensitive and did not destroy the studied HA material [24,25]. 
Vibrational (IR) spectroscopy is a method used to determine the structural fragments of HAs for the analysis of the structure of molecules. The method is based on weakening the intensity of light transmitted through the test substance. This method can be used to determine aliphatic and aromatic structures. Nevertheless, this method, in comparison with ${ }^{13} \mathrm{C}-\mathrm{NMR}$, has lower accuracy due to the fact that when determining any group of structural fragments in the HA molecule, the group is not isolated from the rest of the molecule, which leads to a change in the intensity of the transmitted light. Taking into account the high heterogeneity of HAs molecules, absorption bands in the IR spectra can form, which cannot be attributed to vibrations related to any structural fragments [26].

Densitometric fractionation of SOM is a fairly simple and informative way to isolate chemically and biologically heterogeneous structures of organic matter. The method is based on the structural features of SOM; when using this method of analysis, organic matter can be divided into three groups (free, occluded and organo-mineral). Their differences are associated with their composition and resistance to biodegradation $[27,28]$.

One-dimensional (1D) solid-state ${ }^{13} \mathrm{C}$ NMR spectra provide some structural information about HAs, including the quantification of various types of chemical groups $[9,18,20,29,30]$. The advantage of using the method of one-dimensional NMR spectroscopy is the ability to quantitatively determine the content of groups of individual and structural fragments in HA molecules. This method is also used to assess changes in SOM during decomposition and humification. Nowadays, studies of the quality of SOM from the Arctic belt have revealed the generalized, slightly degraded nature of organic molecules that retain most of the chemical nature of their precursor humification material (plants and soil living organisms) due to a weak humification process under cryogenic processes [19]. However, using a 1D structure, the differences among the atoms cannot be characterized in a prominent way due to wide lines and the diversity of the structures of functional groups [31-33]. Using (2D) NMR techniques, such peak overlap can be eliminated, and the chemical structure corresponding to a given chemical shifts can be investigated more specifically and provide additional structural information about dipolar interaction among the unprotonated carbon atoms [31].

For further study of the fundamental processes of humification and structural fragments in polar regions, it is necessary to use modern, high-precision instrumental methods. Analysis of molecular composition is necessary to understand the fundamental processes of SOM transformation and the structures of the natural, high-molecular compounds of humic acids in soils affected by permafrost $[9,20,30,34]$.

In this way, the aim of this work was to use the composition of SOM to deduce trends in the decomposition rates of HAs in Arctic sediments. Thus, the following tasks were set:

- Investigate the elemental composition of HAs separated from soils of the Lena River delta;

- Determine the molecular composition of HAs separated from soils of the Lena River delta;

- $\quad$ Estimate the rate of stabilization of organic matter in the studied soils and buried organic remains.

\section{Materials and Methods}

\subsection{The Study Site}

The Lena River delta is the largest northern delta in the world; it is located in the Arctic zone and has an area of about $30,000 \mathrm{~km}^{2}$. The delta was formed as a result of river activity: sediment removal, erosion, abrasion under the influence of sea level fluctuations and movement of the earth's crust [35] (Figure 1). 


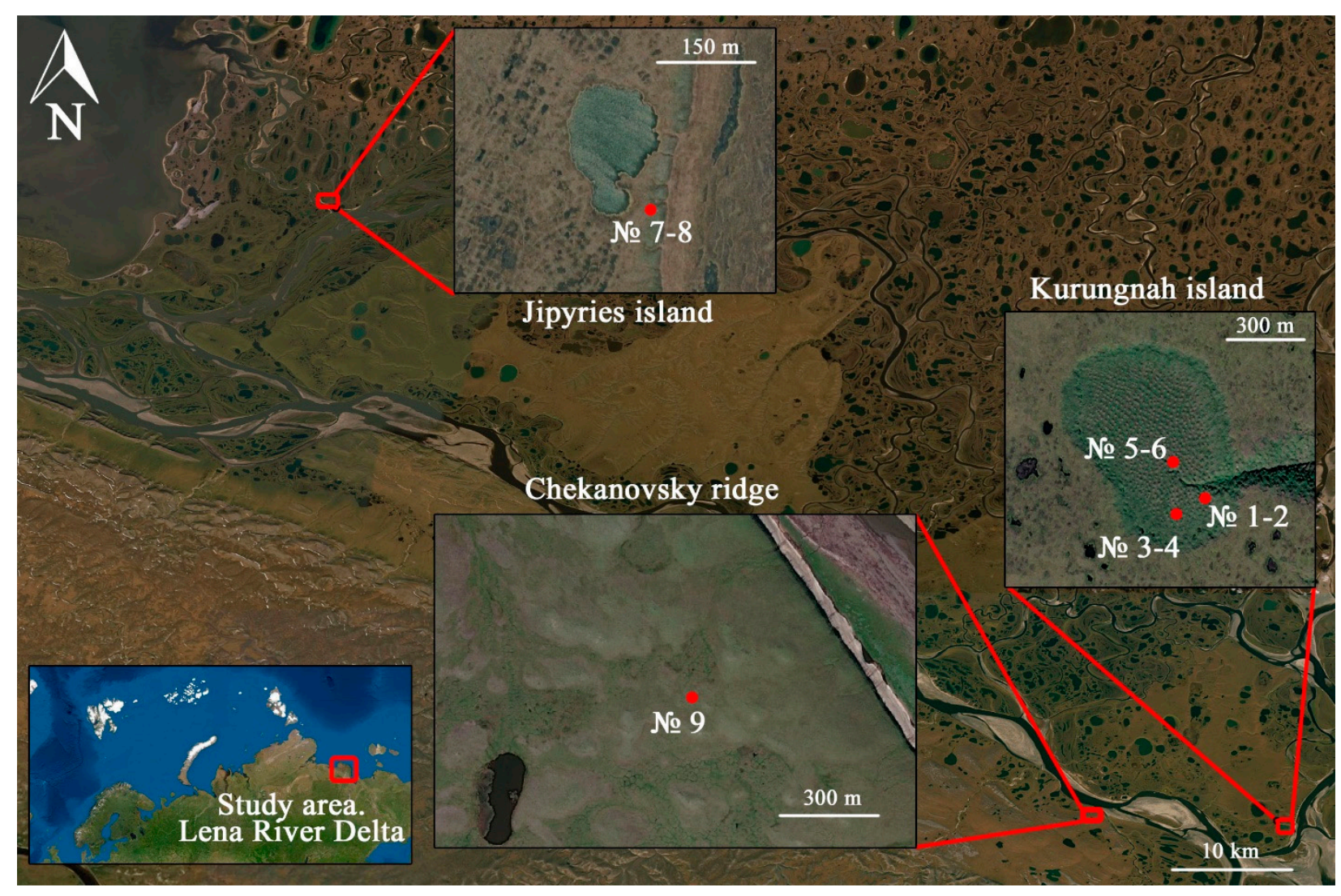

Figure 1. Study area: Lena River delta. Soil numbers correspond to Table 1.

The Lena River delta can be defined by three different geomorphological terraces with active flooded levels. The active flooded level is the first terrace, which is the youngest part of the river delta. The first terrace was formed during the Middle Holocene and is mainly represented in the eastern part of the Lena delta. The second terrace was formed between the Late Pleistocene and the Early Holocene. The polygonal relief is less pronounced, and a large number of thermokarst lakes are typical of this area. The third terrace is the oldest terrace in the Lena delta. It consists of fine-grained sand that is rich in organic matter; it is icy material that accumulated in front of the Chekanovsky and Kharulakh Ridges.

The Lena River delta is located in a zone with an arctic continental climate. The average annual air temperature is $-13{ }^{\circ} \mathrm{C}$; the average January temperature is $-32{ }^{\circ} \mathrm{C}$ and the average July temperature is $-6.5^{\circ} \mathrm{C}$. Annual precipitation is $190 \mathrm{~mm}$. Most of the land is characterized by the presence of permafrost at a depth of about $1 \mathrm{~m}$. The depth of the seasonally thawed layer is different; in depressions it can reach $30 \mathrm{~cm}$ at the end of August, and on the sand materials, up to $1 \mathrm{~m}$.

\subsection{Sampling Procedure}

The sampling and classification procedure of soils and soil horizons was carried out according to the standard procedure [36,37]. In the course of the work, samples were taken from the upper organo-mineral as well as the lower horizons in which suprapermafrost accumulation of organic matter occurred.

The key areas of research were soils from the Kurungnah Islands (third terrace), soils from Jipyries Island (second terrace) and soils from the Chekanovsky Ridge (Table 1). 
Table 1. Description of study sites.

\begin{tabular}{|c|c|c|c|c|c|c|c|c|}
\hline Site & Soil Profile & Location & Soil ID & Description & Color Index & Vegetation & Soil Name & Sampling Date \\
\hline \multirow{3}{*}{$\begin{array}{l}\text { Kurungnah } \\
\text { Isl., third } \\
\text { terrace }\end{array}$} & $\mathrm{Y}-1$ & $\begin{array}{c}\text { Place of drained lake, } \\
\text { pingo with height } 1.5 \mathrm{~m} \text {. } \\
\text { N } 72^{\circ} 19^{\prime} 19.0^{\prime \prime} \\
\text { E } 126^{\circ} 15^{\prime} 21.1^{\prime \prime}\end{array}$ & 1 & $\begin{array}{l}\text { Umbric horizon, roots, moderately } \\
\text { decomposed organic material. } \\
\text { Buried, moderately decomposed } \\
\text { organic material. Permafrost table } \\
\text { from } 50 \mathrm{~cm} .\end{array}$ & $10 \mathrm{YR} 4 / 3$ & $\begin{array}{l}\text { Trisetum, } \\
\text { Phragmites. }\end{array}$ & Umbric Cryosol & 28 August 2019 \\
\hline & $\mathrm{Y}-2$ & $\begin{array}{l}\text { Place of drained lake, } \\
\text { pingo with height } 2 \mathrm{~m} \text {. } \\
\mathrm{N} 72^{\circ} 19^{\prime} 17.7^{\prime \prime} \\
\text { E } 126^{\circ} 15^{\prime} 20.4^{\prime \prime}\end{array}$ & 4 & $\begin{array}{l}\text { Umbric horizon, roots, moderately } \\
\text { decomposed organic material. } \\
\text { Buried, moderately decomposed } \\
\text { organic material. Permafrost table } \\
\text { from } 62 \mathrm{~cm} .\end{array}$ & $10 \mathrm{YR} 4 / 3$ & $\begin{array}{l}\text { Trisetum, } \\
\text { Phragmites. }\end{array}$ & Umbric Cryosol & 28 August 2019 \\
\hline & Y-3 & $\begin{array}{c}\text { Place of drained lake, } \\
\text { pingo with height } 1.8 \mathrm{~m} \text {. } \\
\mathrm{N} 72^{\circ} 19^{\prime} 21.4^{\prime \prime} \\
\mathrm{E} 126^{\circ} 15^{\prime} 16.3^{\prime \prime}\end{array}$ & 6 & $\begin{array}{l}\text { Umbric horizon, roots, moderately } \\
\text { decomposed organic material. } \\
\text { Buried, moderately decomposed } \\
\text { organic material. Permafrost table } \\
\text { from } 56 \mathrm{~cm} .\end{array}$ & $\begin{array}{l}10 \mathrm{YR} 4 / 3 \\
10 \mathrm{YR} 3 / 2\end{array}$ & $\begin{array}{l}\text { Trisetum, } \\
\text { Phragmites. }\end{array}$ & Umbric Cryosol & 5 September 201 \\
\hline $\begin{array}{l}\text { Jipyries Isl., } \\
\text { second terrace }\end{array}$ & S-1 & $\begin{array}{l}\text { Border of termocarst } \\
\text { lake. } \mathrm{N} 72^{\circ} 58^{\prime} 55.1^{\prime \prime} \\
\quad \text { E } 123^{\circ} 48^{\prime} 40.4^{\prime \prime}\end{array}$ & 8 & $\begin{array}{l}\text { Umbric horizon, roots, highly } \\
\text { decomposed organic material. } \\
\text { Buried, highly decomposed } \\
\text { organic material. Permafrost table } \\
\text { from } 41 \mathrm{~cm} \text {. }\end{array}$ & $\begin{array}{l}10 \mathrm{YR} 3 / 2 \\
10 \mathrm{YR} 3 / 2\end{array}$ & $\begin{array}{c}\text { Cetraria nivalis, } \\
\text { Sphagnum, Carex } \\
\text { Aquatilis, Trisetum, } \\
\text { Phragmites. }\end{array}$ & Umbric Cryosol & 5 July 2019 \\
\hline $\begin{array}{l}\text { Chekanovsky } \\
\text { Ridge }\end{array}$ & W-1 & $\begin{array}{l}\text { The wind shelter. } \\
\text { N } 72^{\circ} 19^{\prime} 18.9^{\prime \prime} \\
\text { E } 125^{\circ} 45^{\prime} 59.1^{\prime \prime}\end{array}$ & 9 & $\begin{array}{l}\text { Highly decomposed organic } \\
\text { material in rock shelter. }\end{array}$ & $10 \mathrm{YR} 3 / 2$ & $\begin{array}{l}\text { Trisetum, } \\
\text { Phragmites, } \\
\text { Sphagnum. }\end{array}$ & Umbric Cryosol & 27 August 2019 \\
\hline
\end{tabular}


Soil samples were taken during the 2019 field season. Samples were taken from the superficial soil horizons as well as from the lower horizons located on the permafrost table in order to assess the degree of stabilization of organic matter and study the evolutionary selection of HA molecules within the soil profile. A sample from the Chekanovsky Ridge was taken from a wind shelter inside rocks (Figure 2).

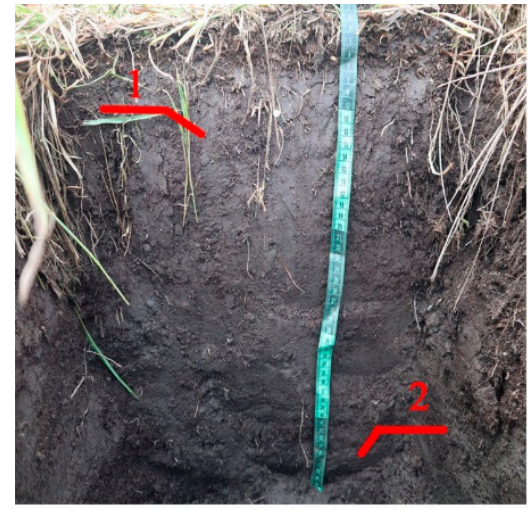

(a)

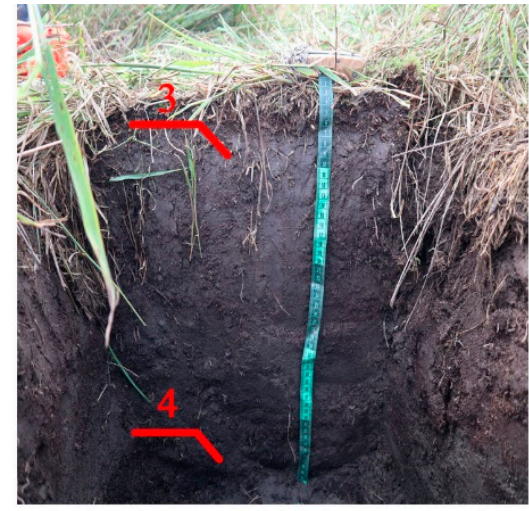

(b)

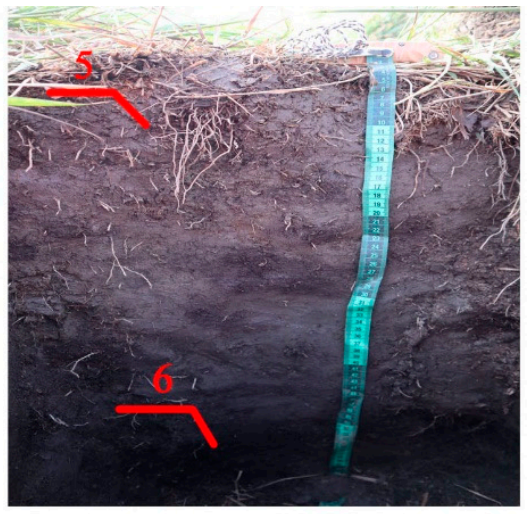

(c)

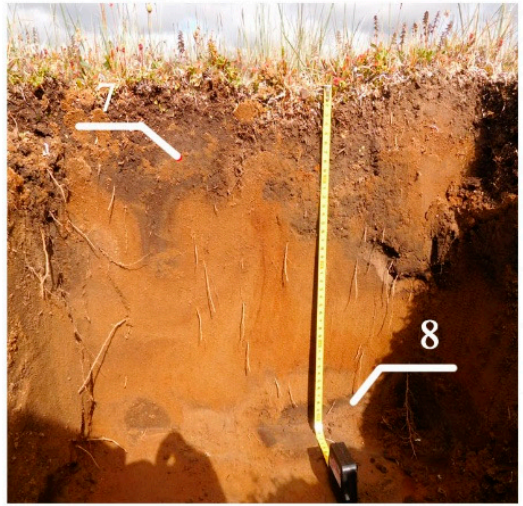

(d)

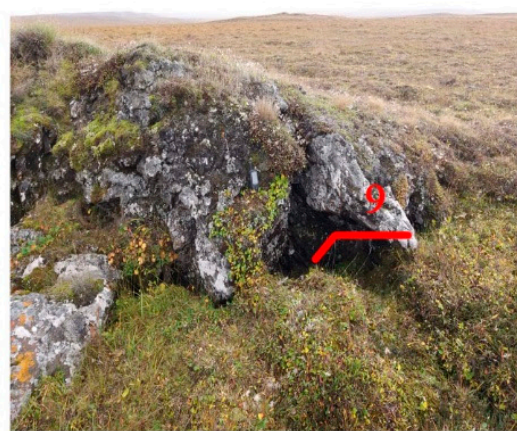

(e)

Figure 2. Study soil profiles. Soil IDs correspond to Table 1, (a-c) Kurungnah Isl., third terrace; (d) Jipyries Isl., second terrace; (e) - Chekanovsky Ridge.

\subsection{Laboratory Analysis}

Soil samples were air-dried $\left(24 \mathrm{~h}, 20^{\circ} \mathrm{C}\right)$, ground and passed through a $2 \mathrm{~mm}$ sieve. Chemical analyses were performed using classical methods: $\mathrm{C}$ and $\mathrm{N}$ content were determined using an element analyzer (EA3028-HT EuroVector, Pavia PV, Italy), their $\mathrm{pH}$ in water (soil-dissolvent ratios were 1:2.5 in the case of mineral horizons and 1:25 in the case of organo-mineral horizons) suspensions using a $\mathrm{pH}$ meter ( $\mathrm{pH}-150 \mathrm{M}$, Teplopribor, Moscow, Russia). The particle-size distribution analysis was carried out according to the Kachinsky "wet sedimentation" method, which is the Russian analogue of analysis by Bowman and Hutka [38].

\subsection{Protocol for the Extraction of Humic Acids from Soils}

Humic acids were extracted according to a published IHSS protocol [39] in modification by Chukov [15] that involved:

- Soil sieving: We manually broke up a portion of the dried soil sample into powder or small portions using a mortar and pestle and sieved the ground sample through $2 \mathrm{~mm}$ mesh; 
- $\quad$ Extraction of humic substances with alkaline solution: Samples of $50 \mathrm{~g}$ for organic soils and $100 \mathrm{~g}$ for organo-mineral soils were filled up to $500 \mathrm{~mL}$ with $\mathrm{NaOH} 0.1 \mathrm{~N}$ solutions and left for $48 \mathrm{~h}$;

- Gravity filtration of the extractant: After $48 \mathrm{~h}$, the soils sedimented to the bottom of the flask, and the supernatant contained $\mathrm{NaOH}$ with extracted humic substances. This supernatant was now separated from the soil by gravity filtration;

- Precipitation of the humic substances: For every sample, we calculated the amount of $\mathrm{H}_{2} \mathrm{SO}_{4} 1 \mathrm{~N}$ solution in the proportion of $50 \mathrm{~mL} \mathrm{H}_{2} \mathrm{SO}_{4} 1 \mathrm{~N}$ per $100 \mathrm{~mL}$ of supernatant. After adding the solutions, we let it stand for $24 \mathrm{~h}$;

- Dialysis of humic acids: Over the previous $24 \mathrm{~h}$, the humic substances precipitated to the bottom of the flask. After $24 \mathrm{~h}$, the supernatant liquid (acid-soluble fraction) was siphoned off, and the HA precipitate was squeezed out in a centrifuge at $3000 \mathrm{rpm}$ for $15 \mathrm{~min}$ and washed in centrifuge beakers with repeated centrifugation, first with acidified sulfuric acid water and then with pure water until the HA began to disperse. After centrifugation and washing, the HA gel was placed in bags made of dialysis cellophane and placed in large containers with distilled water. During the first 3 days, the water was changed every day, and then it was change after 2 days. Usually, it took 7-10 days to completely remove excess sodium sulfate. The completeness of removal was controlled by the qualitative reaction to sulfates in the water flowing down from the bag;

- $\quad$ Drying of HA preparations: HAs preparations from dialysis bags were transferred into Petri dishes or small crystallizers, after which they were dried in a vacuum oven over containers with dry $\mathrm{CaCl}_{2}$. Further, the HA preparations were transferred into weighing bottles and, if necessary, dried in a desiccator over $\mathrm{P}_{2} \mathrm{O}_{5}$. The ash content of the HA preparations obtained by this method did not exceed 5\% and significantly depended on the speed and duration of the first centrifugation.

\subsubsection{Elemental Composition of HAs}

The elemental composition of an HA is the percentage of the elements $\mathrm{C}, \mathrm{H}, \mathrm{N}$ and $\mathrm{O}$. For graphical analysis of the elemental composition, we used the van Krevelen diagram [40], using the $\mathrm{H} / \mathrm{C}$ and $\mathrm{O} / \mathrm{C}$ ratios to determine the direction of the transformation processes of various organic compounds into natural conditions. The elemental composition was corrected for weight moisture and ash content. The oxygen content was calculated from the differences in the masses of the whole samples and the gravimetric concentrations of $C, N$, $\mathrm{H}$ and ash. The determination was carried out in the same way on an elemental analyzer (EA3028-HT EuroVector, Pavia PV, Italy). Ethylenediaminetetraacetic acid disodium salt dehydrate (EDTA) was used as a reference standard in the analysis (CAS Number: 6381-92-6).

\subsubsection{Molecular Composition of HAs}

Solid-state spectra of humic acids were determined by CP/MAS ${ }^{13} \mathrm{C}-\mathrm{NMR}$ spectroscopy on a NMR spectrometer (Bruker Avance 500, Billerica, MA, USA) in a $3.2 \mathrm{~mm}$ $\mathrm{ZrO}_{2}$ rotor. The magic angle rotation speed was $20 \mathrm{kHz}$, and the cross-polarization nutation frequency $\mathrm{u} 1 / 2 \mathrm{p} 1 / 4$ was $62.5 \mathrm{kHz}$. The repetition delay was $3 \mathrm{~s}$. The number of scans was $6500-35,000$. Temperature was $294.5^{\circ} \mathrm{C}$, according to a $4 \mathrm{~mm} \mathrm{MAS} \mathrm{BB/1H}$ H13925/0005 probe.

Molecular weight was calculated using the minimum molecular weight; its value corresponds to the simplest formula of humic acid that is calculated from the elemental composition and determines the lower limit of possible molecular weights [41,42].

\subsubsection{Statistical Survey}

The statistical analysis was performed in Paleontological Statistics (PAST) software.

Principal component analysis

The method is based on projecting a multidimensional dataset of up to several dimensions in such a way as to preserve as much variation as possible and to facilitate data 
visualization. In addition, the axes of maximum variance (principal components) can be identified and interpreted.

Spearman's correlation coefficient

The method is based on measuring the linear relationship between random variables.

Hierarchical clustering: Ward's method.

This analysis uses a method of variance to estimate the distances between clusters. The method minimizes the sum of squares (SS) for any two (hypothetical) clusters that could be formed at each step.

\section{Results and Discussion}

\subsection{The Physico-Chemical Characteristics of Study Soils}

The studied soils were characterized by slightly acidic and neutral $\mathrm{pH}$ reactions (Table 2). This was due to the erosion of carbonate rocks in the middle course of the Lena River; the presence of carbonates was also noted in the ridges adjacent to the delta [43].

Table 2. The physico-chemical parameters of the studied soils.

\begin{tabular}{|c|c|c|c|c|c|c|c|}
\hline \multirow{2}{*}{ Soil ID } & \multirow{2}{*}{$\begin{array}{l}\mathrm{pH} \text { in } \\
\text { Water }\end{array}$} & \multirow{2}{*}{$C, \%$} & \multirow{2}{*}{$\mathbf{N}, \%$} & \multirow{2}{*}{$\mathrm{C} / \mathrm{N}$} & \multicolumn{3}{|c|}{ Particle Size Distribution } \\
\hline & & & & & Clay & Silt & Sand \\
\hline \multicolumn{8}{|c|}{ Kurungnah Isl., third terrace } \\
\hline 1 & 6.45 & 1.82 & 0.14 & 13 & 3 & 32 & 65 \\
\hline 2 & 5.95 & 2.86 & 0.22 & 13 & 6 & 68 & 24 \\
\hline 3 & 6.63 & 1.52 & 0.11 & 14 & 2 & 41 & 57 \\
\hline 4 & 5.33 & 1.44 & 0.13 & 11 & 2 & 47 & 51 \\
\hline 5 & 6.41 & 2.65 & 0.19 & 14 & 3 & 32 & 65 \\
\hline 6 & 5.44 & 2.24 & 0.13 & 17 & 3 & 15 & 82 \\
\hline \multicolumn{8}{|c|}{ Jipyries Isl., second terrace } \\
\hline 7 & 6.32 & 0.55 & 0.06 & 9 & 5 & 13 & 82 \\
\hline 8 & 5.34 & 1.48 & 0.16 & 9 & 6 & 28 & 66 \\
\hline \multicolumn{8}{|c|}{ Chekanovsky Ridge } \\
\hline 9 & 5.99 & 4.32 & 0.36 & 12 & 9 & 64 & 27 \\
\hline $\begin{array}{l}\text { Standard } \\
\text { deviation }\end{array}$ & 0.51 & 1.08 & 0.09 & 3 & 2 & 19 & 21 \\
\hline
\end{tabular}

In the studied soils, relatively little SOM accumulated, with the highest content noted in the wind shelter site, which was associated with more favorable conditions for humification [44]. The enrichment of organic matter with nitrogen is low, according to Orlov [45]. The studied soils were dominated by the sandy fraction, which was associated with the activity of the river and the features of the formation of the delta complex. The low content of the clay fraction was associated with the relatively high speed of the river; in such conditions, mainly large particles (sand, dust) settle [46].

\subsection{Elemental Composition}

The elemental composition of an HA is the most important indicator that determines the progress of humification and oxidation as well as the HA's degree of condensation. The characteristic features of HAs formed under arctic conditions, and especially in soils affected by permafrost, are relatively high $\mathrm{H}$ and low $\mathrm{O}$ concentrations compared to boreal and subboreal soils (Table 3) [30]. 
Table 3. Elemental composition of study HAs separated from soils of the Lena River delta. Soil IDs correspond to Table 1.

\begin{tabular}{|c|c|c|c|c|c|c|c|c|c|}
\hline \multirow{2}{*}{ Soil ID } & \multicolumn{4}{|c|}{ Elemental Composition } & \multicolumn{3}{|c|}{ Atomic Ratio } & \multirow{2}{*}{$\begin{array}{c}\text { Extraction Yields, \% } \\
\text { of SOM }\end{array}$} & \multirow{2}{*}{$\begin{array}{c}\text { Molecular } \\
\text { Weight }\end{array}$} \\
\hline & $\mathrm{N}, \%$ & $\mathrm{C}, \%$ & $\mathrm{H}, \%$ & $\mathrm{O}, \%$ & $\mathrm{H} / \mathrm{C}$ & $\mathrm{O} / \mathrm{C}$ & H/Cmod & & \\
\hline \multicolumn{10}{|c|}{ Kurungnah Isl., third terrace } \\
\hline 1 & 4 & 52 & 5 & 34 & 1.3 & 0.49 & 1.97 & 51 & 1016 \\
\hline 2 & 3 & 49 & 5 & 38 & 1.2 & 0.58 & 2.00 & 45 & 883 \\
\hline 3 & 3 & 45 & 6 & 41 & 1.4 & 0.69 & 2.31 & 50 & 888 \\
\hline 4 & 2 & 45 & 5 & 43 & 1.3 & 0.72 & 2.25 & 52 & 1257 \\
\hline 5 & 4 & 47 & 6 & 38 & 1.4 & 0.61 & 2.22 & 41 & 719 \\
\hline 6 & 4 & 50 & 5 & 36 & 1.3 & 0.53 & 1.97 & 35 & 1905 \\
\hline \multicolumn{10}{|c|}{ Jipyries Isl., second terrace } \\
\hline 7 & 3 & 40 & 5 & 47 & 1.6 & 0.89 & 2.84 & 49 & 854 \\
\hline 8 & 4 & 50 & 5 & 36 & 1.4 & 0.54 & 2.16 & 20 & 1405 \\
\hline \multicolumn{10}{|c|}{ Chekanovsky Ridge } \\
\hline 9 & 4 & 43 & 5 & 43 & 1.4 & 0.75 & 2.41 & 34 & 1466 \\
\hline $\begin{array}{l}\text { Standard } \\
\text { deviation }\end{array}$ & 0.72 & 3.86 & 0.44 & 4.21 & 0.11 & 0.12 & 0.27 & 10 & 383 \\
\hline
\end{tabular}

The studied soils accumulated up to $52 \%$ of carbon in the form of HAs, and the highest content was noted in the organo-mineral horizon in the soils of a drained lake (Y 1-3). This site, a drained lake, was quite different from the typical conditions prevailing on this island (zonal tundra). In the studied soils, there was a thick (up to $25 \mathrm{~cm}$ ) organo-mineral horizon, which formed under the vascular plants. The processes of peat accumulation and active cryogenesis dominated in the soils located outside the drained lake. A characteristic feature of the soils of a drained lake is the presence of buried, medium-decomposed organic remains that accumulate on the permafrost table. Different dynamics of carbon accumulation in the composition of HAs were revealed within the three studied pingos (intra-permafrost ice-cored hill) in the area of a drained lake. In the Y-1 profile, the carbon content decreased with depth and the oxygen content increased. That dynamic could apparently be associated with an increase in oxygen-containing fragments (O-alkyl and anomers) due to an increase in soil hydromorphism (the result of temporary or permanent waterlogging conditions of the soil profile or soil horizon, wherein the amount of moisture exceeded $70-80 \%$ of the total soil moisture capacity) in this pingo. This was also reflected in the closer occurrence of the permafrost table and the height of the pingo $(1.5 \mathrm{~m})$. In pingo $\mathrm{Y}-2$, the same carbon content was observed in the upper and lower organo-mineral horizons, with a slight increase in the oxygen content of the buried organic material (from $41 \%$ to $43 \%$ ). In pingo Y-3, there was an increase in carbon content (from $47 \%$ to $50 \%$ ) and a decrease in oxygen content. The increase in the carbon content in the buried organic horizon may have been associated with the processes of humification and humus accumulation at the boundary with the permafrost. The different dynamics of carbon in the studied organic residues are explained by the high variability of soil formation conditions in this region, the active development of cryogenic landforms (pingos), humus accumulation and soil hydromorphism [47-51].

The $\mathrm{H} / \mathrm{Cmod}$ ratio is an indicator of the stability of HAs in soils [45]. An increase in the proportion of hydrogen in the HA structure indicates the significant development of side chains with $\mathrm{C}-\mathrm{H}, \mathrm{CH}_{2}$ and $\mathrm{CH}_{3}$ groups (aliphatic compounds) $[47,52]$. The lower this indicator, the greater is the process of condensation of monomers into high-molecular substances. In general, this shows a low variation, which is associated with the homogeneous conditions of the formation of organic matter in the Lena River delta. The smallest indicators were noted in the samples of the drained lake (Soil ID numbers1 and 6), which indicated the process of condensation in HA molecules. The greatest value was noted in sample number 7 on the island of Jipyries, the second terrace. The most active cryogenic processes in soils were noted here. This was noted in the morphological characteristics of the soil profile (cryoturbation and suprapermafrost accumulation of organic matter) [53,54]. 
For a graphical representation of the elemental composition of HAs from soils, the method by Kleinhempel and van Krevelen was used (Figure 3). The method was based on the construction of $\mathrm{H} / \mathrm{Cmod}$ and $\mathrm{O} / \mathrm{C}$ diagrams and served as a method to demonstrate the contributions of oxidation and condensation to changes in the elemental composition of HAs.

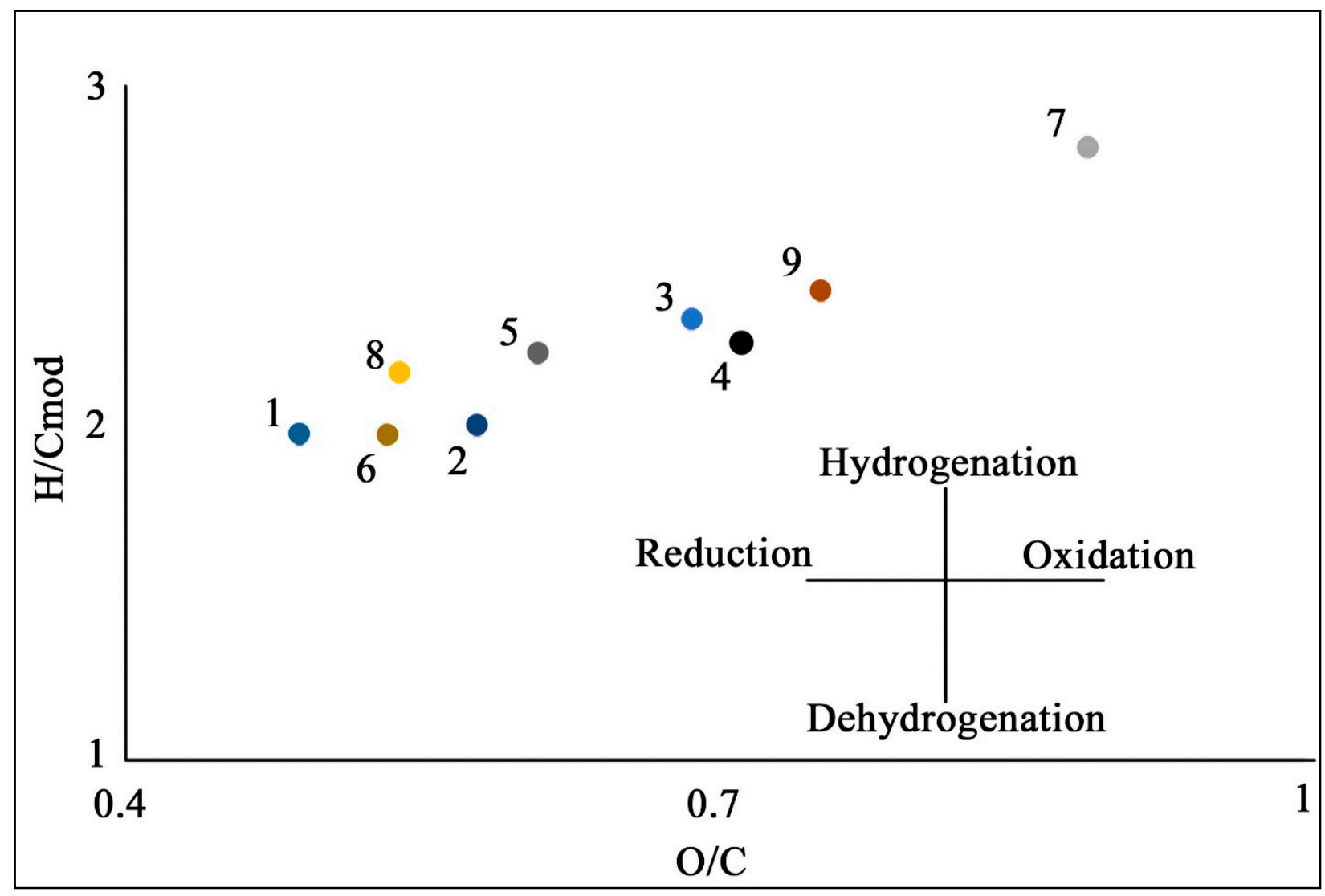

Figure 3. Elemental composition of HAs. Soil IDs correspond to Table 1.

From the data obtained, the integral index of $\mathrm{H} / \mathrm{Cmod}$ and $\mathrm{O} / \mathrm{C}$ in most of the studied HAs was relatively low, which indicated a low content of oxygen-containing fragments in HAs. As mentioned above, high values of $\mathrm{H} / \mathrm{Cmod}$ and $\mathrm{O} / \mathrm{C}$ were observed in the sample from the second terrace (Jipyries Island) and indicated that the sample was formed in an environment with a low level of microbiological activity, which contributed to better preservation of the carbohydrate and amino acid fragments of HAs. A decrease in $\mathrm{H} / \mathrm{Cmod}$ indicated the accumulation of fragments more resistant to biodegradation in the composition of HAs [55]. The most condensed molecules were formed in buried organic remains, which might have been related to the evolutionary selection of stable HA molecules [56,57].

\subsection{Molecular Composition of HAs Separated from the Soils of the Lena River Delta}

Numerous fragments of molecules were identified by $\mathrm{CP} / \mathrm{MAS}{ }^{13} \mathrm{C}$ NMR spectroscopy: carboxyl (-COOR); carbonyl $(-\mathrm{C}=\mathrm{O}) ; \mathrm{CH}^{3-} ; \mathrm{CH}^{2-}$; $\mathrm{CH}-\mathrm{AL}$; $-\mathrm{C}-\mathrm{OR}$ alcohols, esters and carbohydrates; and phenolic $(\mathrm{Ar}-\mathrm{OH})$, quinone $(\mathrm{Ar}=\mathrm{O})$ and aromatic $(\mathrm{Ar}-)$ groups, which indicated the great complexity of the structure of HA [20]. Signals from non-polar alkyls (0-46 ppm), N-alkyl/methoxyl (46-60 ppm), O-alkyl and anomers (60-110 ppm), aromatic compounds (110-160 ppm), carboxyl, esters, amides (160-185 ppm) and quinone (185-200 ppm). The aromatic group was calculated from the sum of the signals from 110-185 ppm. Aliphatic fragments were calculated from the sum of signals from 0-110 ppm and from $180-200 \mathrm{ppm}$. 
The obtained spectra of the studied HAs separated from the soil of the Lena River delta are shown in Figure 4.

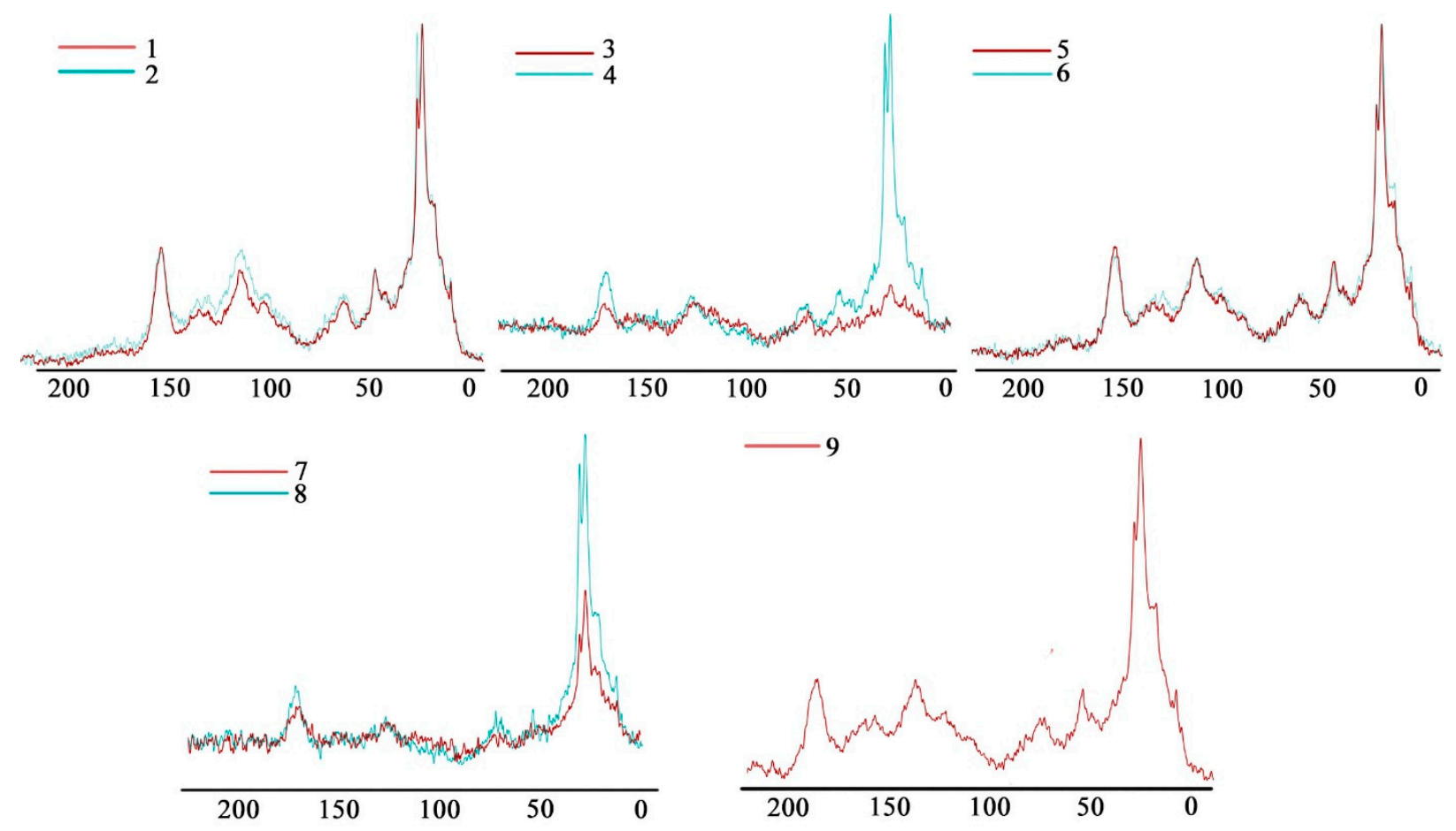

Figure $4 .{ }^{13} \mathrm{C}$ NMR spectra of study HAs separated from soils of the Lena River delta.

The studied HAs accumulated mainly $\mathrm{C}, \mathrm{H}-\mathrm{Alkyl}\left(\left(\mathrm{CH}_{2}\right) \mathrm{n} / \mathrm{CH} / \mathrm{C}\right.$ and $\left.\mathrm{CH}_{3}\right)$, aromatic compounds (C-C/C-H, C-O) and the OCH group (OCH/OCq) (Table 4).

Table 4. Percentage of carbon in the main structural fragments of HAs from the studied soils.

\begin{tabular}{|c|c|c|c|c|c|c|c|c|c|c|c|}
\hline \multirow{2}{*}{ Soil ID } & \multicolumn{6}{|c|}{ Chemical Shifts, \% } & \multirow{2}{*}{ AR } & \multirow{2}{*}{$\mathrm{AL}$} & \multirow{2}{*}{ AR/AL } & \multirow{2}{*}{$\begin{array}{l}\text { AL h,r + } \\
\text { AR h,r * }\end{array}$} & \multirow{2}{*}{$\begin{array}{c}\mathrm{C}, \mathrm{H}-\mathrm{AL} / \\
\mathrm{O}, \mathrm{N}-\mathrm{AL}{ }^{* *}\end{array}$} \\
\hline & $0-46$ & $46-60$ & $60-110$ & $110-160$ & 160-185 & $185-200$ & & & & & \\
\hline 1 & 34 & 7 & 17 & 25 & 11 & 6 & 36 & 64 & 0.53 & 59 & 1.50 \\
\hline 2 & 33 & 7 & 17 & 26 & 11 & 6 & 37 & 63 & 0.58 & 59 & 1.42 \\
\hline 3 & 35 & 7 & 18 & 23 & 10 & 7 & 33 & 67 & 0.48 & 57 & 1.40 \\
\hline 4 & 22 & 6 & 23 & 29 & 11 & 9 & 40 & 60 & 0.68 & 51 & 0.76 \\
\hline 5 & 33 & 7 & 18 & 24 & 11 & 7 & 35 & 65 & 0.54 & 57 & 1.32 \\
\hline 6 & 35 & 7 & 17 & 25 & 10 & 6 & 35 & 65 & 0.53 & 60 & 1.50 \\
\hline 7 & 33 & 6 & 19 & 23 & 11 & 8 & 34 & 66 & 0.52 & 56 & 1.32 \\
\hline 8 & 38 & 6 & 19 & 20 & 10 & 7 & 30 & 70 & 0.42 & 58 & 1.56 \\
\hline 9 & 26 & 7 & 21 & 28 & 12 & 6 & 40 & 60 & 0.65 & 54 & 0.93 \\
\hline
\end{tabular}

* The AL h,r + AR h,r parameter is the total fraction of unoxidized carbon atoms, i.e., substituted with hydrogen atoms or other aliphatic fragments (the sum of the $0-46$ and 110-160 group). ${ }^{* *}$ The $\mathrm{C}, \mathrm{H}-\mathrm{AL} / \mathrm{O}, \mathrm{N}-\mathrm{AL}$ parameter is the degree of decomposition of organic matter.

The studied HAs accumulated up to $71 \%$ of aliphatic fragments. The highest content was noted in the organic matter accumulating at the permafrost table in the profile from the Jipiries Island (second terrace). The predominance of aliphatic fragments indicated a deficiency of vascular plants or the low «maturation» of humic substances in the soil. The predominance of aliphatic structures was characteristic of humic substances formed under reduction conditions including aqueous humic substances [18,19,45,48].

In the studied HAs isolated from pingos, weak dynamics in the molecular composition could be noted. In Y-1, there was a slight increase in aromatic fragments (aromatic C-O) in the buried remains. This was apparently related to the evolutionary selection of stable macromolecules over time. This was also noted in Y-2. Normally, buried substances have a 
more stable structure, which is noted in a number of other investigated works. The soils of the Lena River delta are formed in soft climatic conditions in contrast to the soils that form in continental parts at the same latitude.

In the samples from the island of Jipyries, negative dynamics were observed, with a decrease in aromatic compounds with depth [58]. This was apparently due to the low content of lignin-containing fragments in the precursors of humification $[15,20]$. Due to the hydrogenation process, the C-C chains could be broken, and the aromatic structures in the composition of humic acids could degrade [34,45,51].

The highest contents of aromatic structures were observed in the sample of buried material in Y-2 as well as in the sample from the wind shelter (number 9). The formation of such sites apparently led to the accumulation of high-molecular compounds in the structures of HAs. Under the conditions of wind shelters, the formation of soil horizons was less influenced by climatic features and the microclimate was more stable, which had a positive effect regarding an increase in the content of aromatic structures as well as resistance to biodegradation.

\subsection{The Stabilization of Organic Matter Based on ${ }^{13}$ C NMR Spectroscopy}

The studied samples accumulated up to $40 \%$ aromatic structures (aromatic C and -COOR fragments). This content was relatively high in relation to the soils in the continental part of the Arctic belt. Soil cryogenesis, climatic features and humification precursors have a rather strong effect on the molecular composition of HAs. Low microbiological activity, a relatively high level of hydromorphism in Cryosols and the predominance of moss and lichens in the plant composition lead to the accumulation of aliphatic fragments. In the studied soils, the vegetation cover was dominated by vascular plants, in which up to $30 \%$ of lignin-containing fragments were accumulated [59]. Under conditions of demitylation, during the decomposition of lignin, the HA structure accumulates a carboxyl group, which leads to the stabilization of organic matter $[8,9,21,23,30,32,34,52,58]$.

Under the conditions of the transformation of mosses and lichens, carbohydrates (mono- and oligosaccharides, cellulose, fats, alcohols) come into the soil $[26,45,56]$. During their transformation, aliphatic acids with a content of fatty acids and paraffins are predominantly formed. Plant residues are the sources of various chemical structures, while the formation of aliphatic and aromatic structures is largely associated with the activity of the soil microbiota. The increase in the proportion of aliphatic fragments is associated with a high content of carbohydrates in plant residues as well as the possibility of producing these fragments by the soil microbiota itself. These substances are a larger part of the biochemical cycle and are consumed faster by living organisms $[18,49,60,61]$.

Lignin makes the greatest contribution to the aromaticity of molecules [59]. This component is relatively resistant to biodegradation. It is an irregular polymer with branched macromolecules built from residues substituted by phenol alcohols. This leads to the possibility of the appearance of a large number of various products of its decomposition. Depending on the composition of plant residues, methoxyl groups of compounds as well as various alcohols can form. In organogenic and peat horizons, various resins and waxes, which consist of esters, mono and dihydric alcohols, accumulate to a greater extent $[7,18,21,42,45,49,60,61]$.

In our study, a change in the molecular composition of soil profiles was noted. Under the conditions of transformation of various compounds (carbohydrates, arenas), the condensation of molecules and the formation of various compounds occurred. The longer this process, the more stable molecules accumulated in the HAs, which led to the stabilization of the organic material. HAs are compounds of variable composition. Therefore, their transformation/condensation over time is associated with the evolutionary selection of fragments that are more resistant to biodegradation.

To standardize the quantitative characteristics of HA molecules, the following parameters were used: the degree of decomposition of organic matter (C-alkyl/O-alkyl) and the integral index of HA hydrophobicity (AL h, r + AR h, r) (Figure 5). 


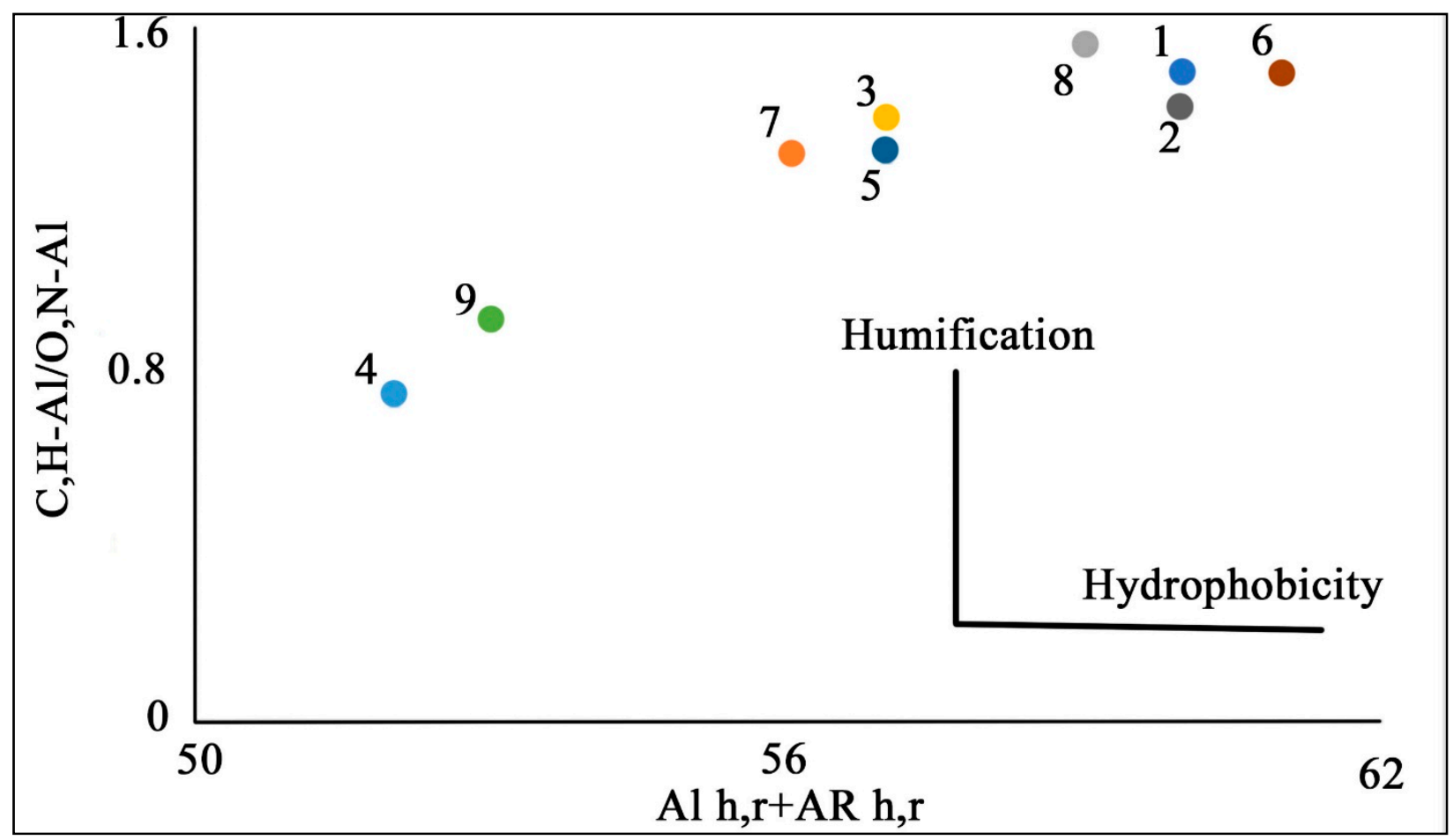

Figure 5. The diagram of integrated indicators of the molecular composition of HAs. Soil IDs correspond to Table 1.

From the data obtained, we noted that the most humified remains were formed in buried organic remains (numbers 6,2,8). The increased proportion of aromatic substances was associated with local position in the relief, the duration of the humification process, wind conditions, hydromorphism of the territory and the precursors of humification (vegetation) [44]. According to degradation hypotheses, stable plant and microbial biopolymers, during transformation, form aromatic benzene rings and labile aliphatic fragments are almost completely mineralized. Soil contains a wide range of various enzymes; various chemical reactions take place here at the same time. The most rapidly mineralized residues are carbohydrates and amino acids $[24,25,31,32,34,62,63]$ and then oligo- and polysaccharides and lignin. The most stable compounds are organic substances of a "secondary" nature, which are products that are formed when the initial substances change (condensed macromolecules). The high stability of such compounds is explained by the fact that they have already passed the stage of biochemical transformations and are now capable of only certain limited reactions, for example, with molecular oxygen. On the other hand, these substances have acquired structural features that different from typical bioorganic molecules. As a result, they gradually become less susceptible to the effects of enzymes, narrowly specialized for strictly defined substrates. Thus, these substances represent the first forms of thermodynamically stable organic carbon compounds outside living organisms under the conditions of the soil cover. HAs are able to persist in soils for quite a long time; the age of such compounds can reach up to 35 thousand years. They give soil stability and buffering capacity as well as a certain biochemical background [30,45,60,61].

Long-term processes of humification under the influence of cryogenesis and low microbiological activity contribute to the formation of thermodynamically stable compounds and lead to the storage of organic carbon in the permafrost state. An increase in the degree of hydrophobicity in HA molecules is also associated with the degradation of organic matter. At a high level of hydrophobicity of molecules, hydrogen does not attach to the double and triple bonds of carbon and prevents the breaking of these bonds and the degradation of organic compounds in the structure of HAs. Buried organic matter serves as a reliable indicator of the processes taking place in soils because it is able to preserve the molecular structure $[45,55,64]$. 
Statistical analysis using Spearman's correlation and analysis of principal components in the composition of HAs was performed (Figures 6 and 7).

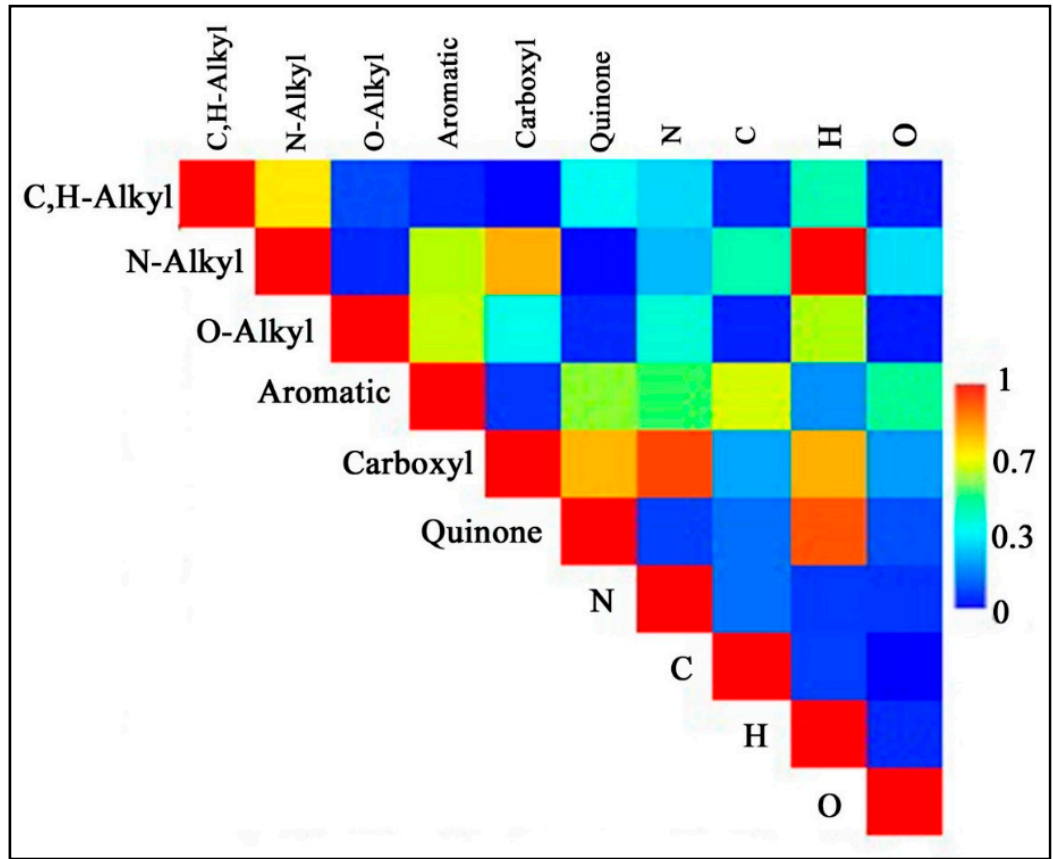

Figure 6. Spearman's correlation matrix of HA fractions and biogenic elements.

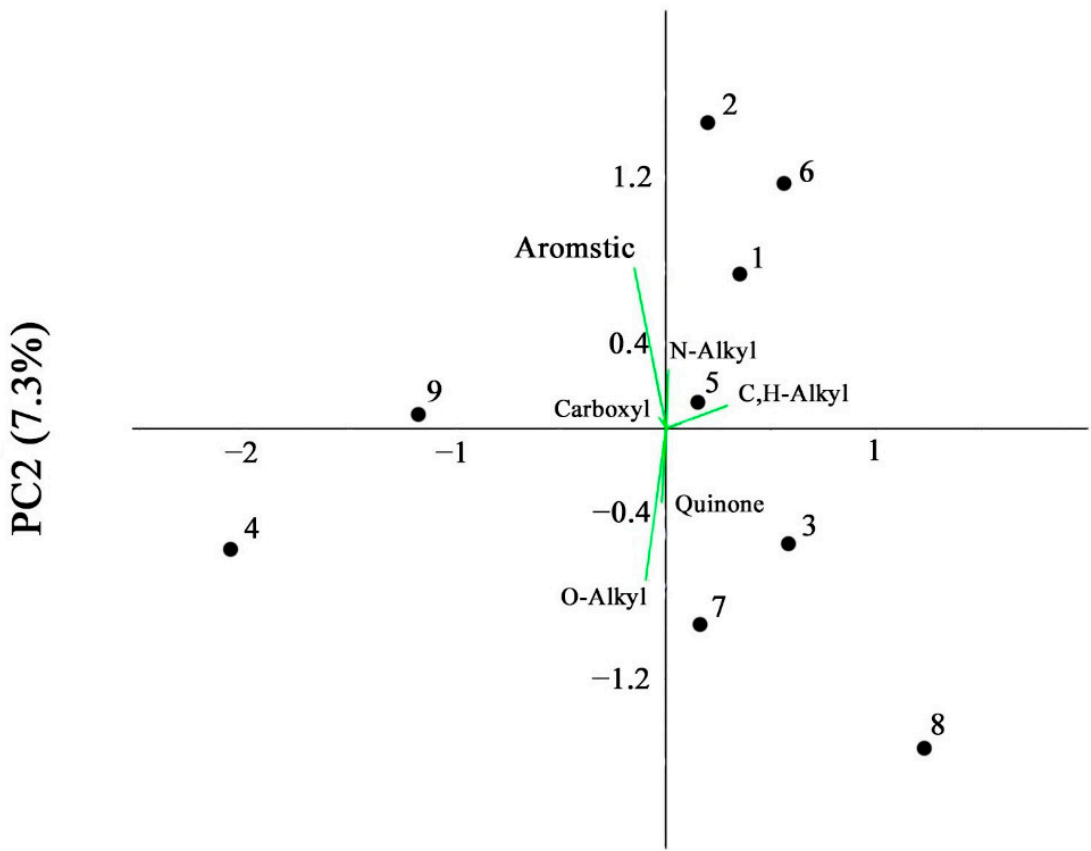

PC1 (89.5\%)

Figure 7. Representation of the samples of humic acids in the plane defined by the first two axes obtained by principal component analysis ( $96 \%$ of the total variance explained).

High correlation was observed in the nitrogen with carboxyl group $(\mathrm{r}=0.9)$, hydrogen with $\mathrm{N}$-alkyl $(\mathrm{r}=1)$ and hydrogen with quinone $(\mathrm{r}=0.89)$. As we said earlier, the composition of HAs from cryoconites varies greatly depending on biological (biochemical) processes, which is reflected in the elemental and qualitative composition of HAs. 
Based on the statistical analysis, it could be concluded that there was a high correlation between the studied samples associated with aliphatic fragments (C,H-Alkyl PC1 (89.5\%)) and aromatic fragments PC2 (7.3\%). Thus, the formation of long aliphatic chains presented in lipids (fatty acids, paraffins), which were the result of the decomposition of moss/lichen residues and the activity of microorganisms. The accumulation of aromatic compounds was associated with the long-term transformation of lignin-containing components in the composition of vascular plants. In general, $\mathrm{C}, \mathrm{H}-\mathrm{Alkyl}$ and carboxylic acids corresponded to the composition of HAs separated from the studied soils. To identify differences between the studied samples, cluster analysis (Ward's method) was carried out (Figure 8).

Tree Diagram for 9 Cases

Ward's method

Euclidean distances

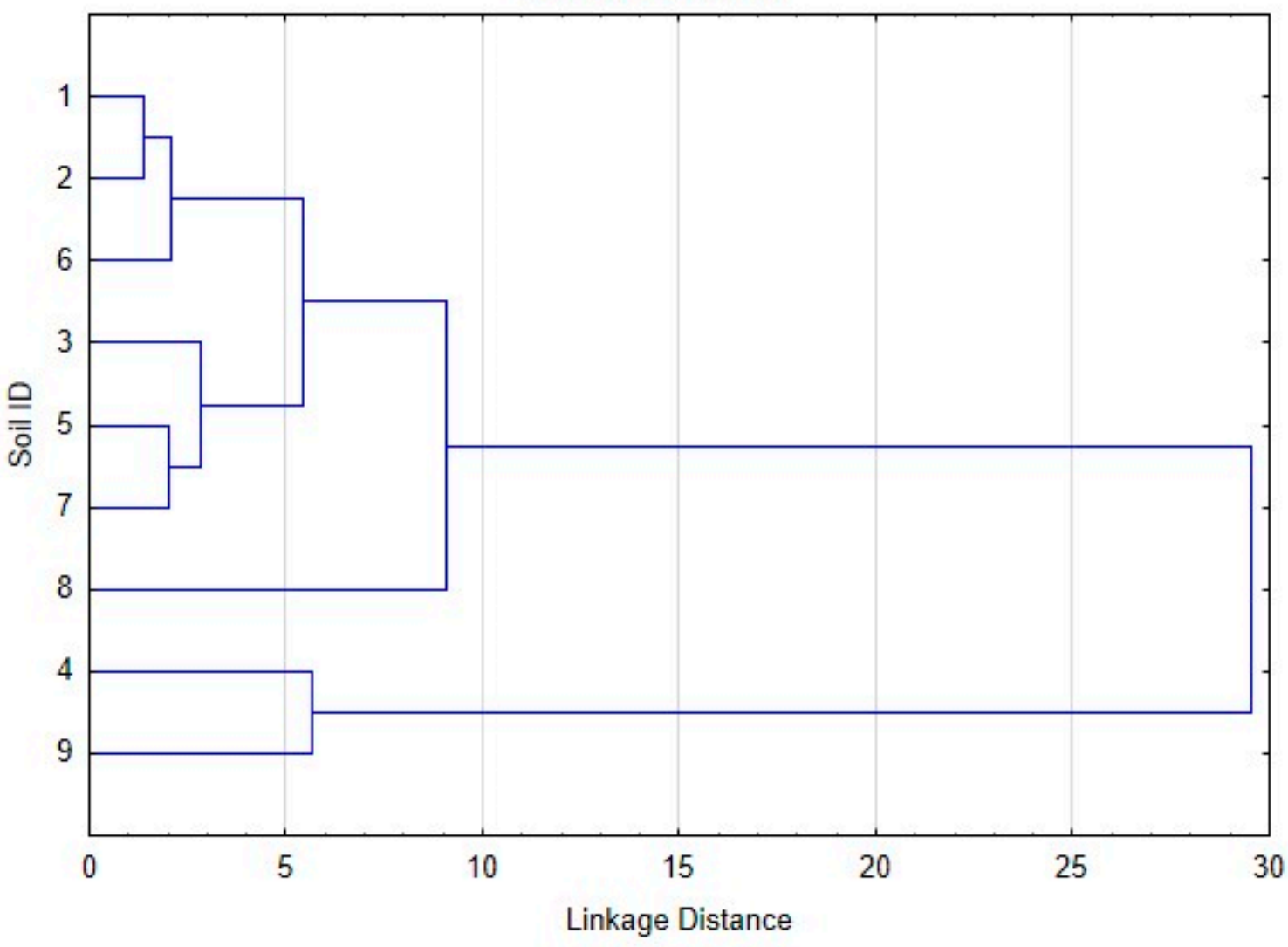

Figure 8. Hierarchical clustering: Ward's method.

Based on the data obtained, we could distinguish two groups that were closest in terms of values (Soil ID 4, 9 and Soil ID 1-3, 5-8). The greatest differences were observed between the studied groups.

Our data corresponded with previously published materials from scientists working in the Arctic belt $[9,45,47,52,55,64,65]$. The increase of aliphatic HA fragments was associated with the specific composition of the vegetation cover and the microbiological composition and activity of the soil as well as climatic conditions [30]. The tundra and taiga zones are characterized by the predominance of moss and lichen vegetation, which is a source of carbohydrates and various lipids. Depending on the climatic zone (tundra, taiga, etc.), the dynamics of the contents of aliphatic and aromatic fragments were noted; in more southern areas, an increase in aromatic fragments occurred, which was associated with a change in vegetation cover and in the climate of the territory $[34,48,51,52]$. Thus, the annual changes in climatic parameters, cryogenic processes and precursors of humification determined the composition of HAs in the study area. The predominance of 
moss/lichen communities contributed to the formation of variable aliphatic chains in HA molecules. The replacement of plant communities with vascular plants and the alternation of wet and dry seasons promoted the condensation and demitylation of aromatic and carboxyl fragments of HAs, which were associated with the resistance of organic material to biodegradation $[18,20,23,24,31,34,47,52,60]$.

\section{Conclusions}

In the soils of the Lena River delta, there is an active accumulation of aliphatic fragments in the composition of Has of up to $70 \%$. Within the profile dynamics, the processes of transformation of aliphatic compounds into aromatic ones were traced. Long-term formation ("maturation") of HAs led to an increase in the content of aromatic fragments in the buried organic matter. Evolutionary thermodynamic selection of condensed molecules led to the stabilization of organic matter and its deposition in the permafrost. It was noted that in soils formed under relatively homogeneous conditions (wind shelters), a relatively high content of aromatic fragments in the composition of HAs accumulated. Climatic features, microbiological activity and precursors of humification as well as time played important roles in the formation of stable ("mature") organic matter.

Author Contributions: V.P. performed the expedition with fieldwork and soil sampling; V.P. and E.A. wrote the paper. All authors have read and agreed to the published version of the manuscript.

Funding: This work was supported by a grant from the Russian Foundation for Basic Research, No. 19-05-50107.

Acknowledgments: Authors thanks Research park of Saint-Petersburg State University (Research Center of Chemical Analyses and Materials and Center of Magnetic Resonance Research).

Conflicts of Interest: The authors declare no conflict of interest.

\section{References}

1. Jones, A.; Stolbovoy, V.; Tarnocai, C.; Broll, G.; Spaargaren, O.; Montanarella, L. Soil Atlas of the Northern Circumpolar Region, European Commission; Publications Office of the European Union: Luxembourg, 2010; p. 144.

2. Davis, T.N. Permafrost: A Guide to Frozen Ground in Transition; University of Alaska Press: Fairbanks, AK, USA, 2001.

3. Dutta, K.; Schuur, E.A.G.; Neff, J.C.; Zimov, S.A. Potential carbon release from permafrost soils of Northeastern Siberia. Glob. Chang. Biol. 2006, 12, 2336-2351. [CrossRef]

4. Schimel, D.S. Terrestrial ecosystems and the carbon cycle. Glob. Chang. Biol. 1995, 1, 77-91. [CrossRef]

5. Zubrzycki, S.; Kutzbach, L.; Grosse, G.; Desyatkin, A.; Pfeiffer, E.M. Organic carbon and total nitrogen stocks in soils of the Lena River Delta. Biogeosciences 2013, 10, 3507-3524. [CrossRef]

6. Zubrzycki, S.; Kutzbach, L.; Pfeiffer, E.M. Permafrost-affected soils and their carbon pools with a focus on the Russian Arctic. Solid Earth 2014, 5, 595-609. [CrossRef]

7. Semenov, V.M.; Ivannikov, L.A.; Tulina, A.S. Stabilization of organic matter in the soil. Agrochimia 2009, 10, 77-96.

8. Cauwet, G.; Sidorov, I. The biogeochemistry of Lena River: organic carbon and nutrients distribution. Mar. Chem. 1996, 53, 211-227. [CrossRef]

9. Ejarque, E.; Abakumov, E. Stability and biodegradability of organic matter from Arctic soils of Western Siberia: insights from 13C-NMR spectroscopy and elemental analysis. Solid Earth 2016, 7, 153-165. [CrossRef]

10. Knoblauch, C.; Beer, C.; Sosnin, A.; Wagner, D.; Pfeiffer, E.-M. Predicting long-term carbon mineralization and trace gas production from thawing permafrost of Northeast Siberia. Glob. Chang. Biol. 2013, 19, 1160-1172. [CrossRef]

11. Kutzbach, L.; Wagner, D.; Pfeiffer, E.-M. Effect of microrelief and vegetation on methane emission from wet polygonal tundra, Lena Delta, Northern Siberia. Biogeochemistry 2004, 69, 341-362. [CrossRef]

12. Lara, R.J.; Rachold, V.; Kattner, G.; Hubberten, H.W.; Guggenberger, G.; Skoog, A.; Thomas, D.N. Dissolved organic matter and nutrients in the Lena River, Siberian Arctic: Characteristics and distribution. Mar. Chem. 1998, 59, 301-309. [CrossRef]

13. Makeev, O. The Soil Cryology; Russian Academy of Science: Moscow, Russian, 2019; p. 464.

14. Kholodov, V.A.; Konstantinov, A.I.; Kudryavtsev, A.V.; Perminova, I.V. Structure of humic acids in zonal soils from 13C NMR data. Eurasian Soil Sci. 2011, 44, 976-983. [CrossRef]

15. Zavarzina, A.G.; Kravchenko, E.G.; Konstantinov, A.I.; Perminova, I.V.; Chukov, S.N.; Demin, V.V. Comparison of the Properties of Humic Acids Extracted from Soils by Alkali in the Presence and Absence of Oxygen. Eurasian Soil Sci. 2019, 52, 880-891. [CrossRef]

16. Piccolo, A.; Nardi, S.; Concheri, G. Macromolecular changes of humic substances induced by interaction with organic acids. Eur. J. Soil Sci. 1996, 47, 319-328. [CrossRef] 
17. Perminova, I.V. Size exclusion chromatography of humic substances: complexities of data interpretation attributable to non-size exclusion effects. Soil Sci. 1999, 164. [CrossRef]

18. Chukov, S.N.; Abakumov, E.V.; Tomashunas, V.M. Characterization of humic acids from antarctic soils by nuclear magnetic resonance. Eurasian Soil Sci. 2015, 48, 1207-1211. [CrossRef]

19. Dziadowiec, H.; Gonet, S.; Plichta, W. Properties of humic acids of Arctic tundra soils in Spitsbergen. Pol. Polar Res. 1994, vol. 15, 71.

20. Lodygin, E.D.; Beznosikov, V.A.; Vasilevich, R.S. Molecular Composition of Humic Substances in Tundra Soils (C-13-NMR Spectroscopic Study). Eurasian Soil Sci. 2014, 47, 400-406. [CrossRef]

21. Piccolo, A. Chapter 5 - Humus and Soil Conservation. In Humic Substances in Terrestrial Ecosystems; Piccolo, A., Ed.; Elsevier Science B.V.: Amsterdam, The Netherlands, 1996; pp. 225-264. [CrossRef]

22. Saiz-Jimenez, C. Chapter 1 - The Chemical Structure of Humic Substances: Recent Advances. In Humic Substances in Terrestrial Ecosystems; Piccolo, A., Ed.; Elsevier Science B.V.: Amsterdam, The Netherlands, 1996; pp. 1-44. [CrossRef]

23. Chen, J.; Gu, B.; LeBoeuf, E.J.; Pan, H.; Dai, S. Spectroscopic characterization of the structural and functional properties of natural organic matter fractions. Chemosphere 2002, 48, 59-68. [CrossRef]

24. Cocozza, C.; D'Orazio, V.; Miano, T.M.; Shotyk, W. Characterization of solid and aqueous phases of a peat bog profile using molecular fluorescence spectroscopy, ESR and FT-IR, and comparison with physical properties. Org. Geochem. 2003, 34, 49-60. [CrossRef]

25. Senesi, N. Application of Electron Spin Resonance (ESR) Spectroscopy in Soil Chemistry. In Advances in Soil Science; Stewart, B.A., Ed.; Springer: New York, NY, USA, 1990; Volume 14, pp. 77-122.

26. Thompson, S.O.; Chesters, G. Infra-red spectra and differential thermograms of lignins and soil humic materials saturated with different cations. J. Soil Sci. 1970, 21, 265-272. [CrossRef]

27. Ovsepyan, L.A.; Kurganova, I.N.; Lopes de Gerenyu, V.O.; Kuzyakov, Y.V.; Rusakov, A.V. Changes in the fractional composition of organic matter in the soils of the forest-steppe zone during their postagrogenic evolution. Eurasian Soil Sci. 2020, 53, 50-61. [CrossRef]

28. Fedotov, G.N.; Artem'eva, Z.S. Colloidal component of granulodensimetric soil fractions. Eurasian Soil Sci. $2015,48,54-62$. [CrossRef]

29. Dai, X.Y.; Ping, C.L.; Michaelson, G.J. Characterizing soil organic matter in Arctic tundra soils by different analytical approaches. Org. Geochem. 2002, 33, 407-419. [CrossRef]

30. Lupachev, A.; Abakumov, E.; Gubin, S. The Influence of Cryogenic Mass Exchange on the Composition and Stabilization Rate of Soil Organic Matter in Cryosols of the Kolyma Lowland (North Yakutia, Russia). Geosciences 2017, 7, 24. [CrossRef]

31. Burdelnaya, N.; Bushnev, D.; Mokeev, M.; Dobrodumov, A. Experimental study of kerogen maturation by solid-state 13C NMR spectroscopy. Fuel 2014, 118, 308-315. [CrossRef]

32. Cao, X.; Lattao, C.; Pignatello, J.J.; Mao, J.; Schmidt-Rohr, K. Sorption Selectivity in Natural Organic Matter Probed with Fully Deuterium-Exchanged and Carbonyl-13C-Labeled Benzophenone and 1H-13C NMR Spectroscopy. Environ. Sci. Technol. 2014, 48, 8645-8652. [CrossRef] [PubMed]

33. Holland, G.P.; Alam, T.M. Multi-dimensional 1H-13C HETCOR and FSLG-HETCOR NMR study of sphingomyelin bilayers containing cholesterol in the gel and liquid crystalline states. J. Magn. Reson. 2006, 181, 316-326. [CrossRef]

34. Perminova, I.V.; Garcia-Mina, J.M.; Podgorski, D.C.; Cervantes, F.J.; Efremenko, E.N.; Domingo, J.L. Humic substances and living systems: Impact on environmental and human health. Environ. Res. 2021, 194. [CrossRef] [PubMed]

35. Bolshiyanov, D.Y.; Makarov, A.S.; Schneider, V.; Stoof, G. Origin and Development of the delta Lena River; AARI: St. Petersburg, Russia, 2013; p. 268.

36. WRB, F. IUSS Working Group WRB World Reference Base for Soil Resources 2014, Update 2015. p. 195. Available online: http:/ / www.fao.org/3/i3794en/I3794en.pdf (accessed on 16 June 2021).

37. Jahn, R.; Blume, H.P.; Spaargaren, O.; Schad, P. Guidelines for Soil Description; Food and Agriculture Organization of the United Nations: Rome, Italy, 2006.

38. Bowman, G.; Hutka, J. Particle Size Analysis. In Soil Physical Measurment and Interpritation for Land Evaluation; McKezie, N., Coughlan, K., Cresswell, H., Eds.; CSIRO Publishing: Victoria, Australia, 2002; pp. 224-239.

39. Swift, R.S. Organic Matter Characterization. Methods Soil Anal. 1996, 1011-1069. [CrossRef]

40. van Krevelen, D.W. Studies of gas absorption. VI. A graphical representation for the efficiency of physical absorption. Recl. Des Trav. Chim. Des Pays-Bas 1950, 69, 503-508. [CrossRef]

41. Harwood, H.J. Minimum molecular weight approach for determining empirical formulas. J. Chem. Educ. 1965, 42, 222. [CrossRef]

42. Orlov, D.S. Soil Chemistry: A Textbook; Moscow State University: Moscow, Russia, 1985.

43. Izokh, N.; Yazikov, A. Discovery of Early Carboniferous conodonts in Northern Kharaulakh Ranges (lower reaches of the Lena River, northeastern Siberia, Arctic Russia). Revue de Micropaléontologie 2017, 60, 213-232. [CrossRef]

44. Abakumov, E.V.; Rodina, O.A.; Eskov, A.K. Humification and Humic Acid Composition of Suspended Soil in Oligotrophous Environments in South Vietnam. Appl. Environ. Soil Sci. 2018, 2018, 1026237. [CrossRef]

45. Orlov, D.S. Soil Humic Acids and General Theory Humification; Moscov State University: Moscow, Russia, $1990 ;$ p. 325.

46. Dobrovolsky, G.V. Soils of floodplains of the center of Russian plain. M. Publ. House Mosc. Univ. 2005, $2025,293$.

47. Abakumov, E.; Lodygin, E.; Tomashunas, V. 13C NMR and ESR characterization of humic substances isolated from soils of two siberian Arctic Islands. Int. J. Ecol. 2015. [CrossRef] 
48. Abakumov, E.; Maksimova, E.; Tsibart, A. Assessment of postfire soils degradation dynamics: Stability and molecular composition of humic acids with use of spectroscopy methods. Land Degrad. Dev. 2018, 29, 2092-2101. [CrossRef]

49. Hatcher, P.G.; Schnitzer, M.; Dennis, L.W.; Maciel, G.E. Aromaticity of Humic Substances in Soils. Soil Sci. Soc. Am. J. 1981, 45, 1089-1094. [CrossRef]

50. Polyakov, V.; Abakumov, E.V. Humic Acids Isolated from Selected Soils from the Russian Arctic and Antarctic: Characterization by Two-Dimensional 1H-13C HETCOR and 13C CP/Mas NMR Spectroscopy. Geosciences 2020, 10. [CrossRef]

51. Polyakov, V.I.; Chegodaeva, N.A.; Abakumov, E.V. Molecular and elemental composition of humic acids isolated from selected soils of the Russian Arctic. Vestn. Tomsk. Gos. Univ. Biol. 2019, 47, 6-21. [CrossRef] [PubMed]

52. Beznosikov, V.A.; Lodygin, E.D. High-molecular organic substances in soils. Trans. Komi Sci. Cent. Ural Branch Russ. Acad. Sci. 2010, 1, 24-30.

53. Schaefer, C.E.G.R.; Simas, F.N.B.; Gilkes, R.J.; Mathison, C.; da Costa, L.M.; Albuquerque, M.A. Micromorphology and microchemistry of selected Cryosols from maritime Antarctica. Geoderma 2008, 144, 104-115. [CrossRef]

54. Szymański, W.; Skiba, M.; Wojtun, B.; Drewnik, M. Soil properties, micromorphology, and mineralogy of Cryosols from sorted and unsorted patterned grounds in the Hornsund area, SW Spitsbergen. Geoderma 2015, 253-254, 1-11. [CrossRef]

55. Pengerud, A.; Dignac, M.-F.; Certini, G.; Strand, L.T.; Forte, C.; Rasse, D.P. Soil organic matter molecular composition and state of decomposition in three locations of the European Arctic. Biogeochemistry 2017, 135, 277-292. [CrossRef]

56. Vasilevich, R.; Lodygin, E.; Beznosikov, V.; Abakumov, E. Molecular composition of raw peat and humic substances from permafrost peat soils of European Northeast Russia as climate change markers. Sci. Total Environ. 2018, 615, 1229-1238. [CrossRef] [PubMed]

57. Vasilevich, R.S.; Beznosikov, V.A.; Lodygin, E.D. Molecular Structure of Humus Substances in Permafrost Peat Mounds in Forest-Tundra. Eurasian Soil Sci. 2019, 52, 283-295. [CrossRef]

58. Polyakov, V.; Abakumov, E. Stabilization of organic material from soils and soil-like bodies in the Lena River Delta (13C-NMR spectroscopy analysis). Span. J. Soil Sci. 2020, 10, 170-190. [CrossRef]

59. Fedoros, E.I.; Baldueva, I.A.; Perminova, I.V.; Badun, G.A.; Chernysheva, M.G.; Grozdova, I.D.; Melik-Nubarov, N.S.; Danilova, A.B.; Nekhaeva, T.L.; Kuznetsova, A.I.; et al. Exploring bioactivity potential of polyphenolic water-soluble lignin derivative. Environ. Res. 2020, 191, 110049. [CrossRef]

60. Lodygin, E.; Beznosikov, V.; Abakumov, E. Humic substances elemental composition of selected taiga and tundra soils from Russian European North-East. Pol. Polar Res. 2017, 38, 125-147. [CrossRef]

61. Lodygin, E.D.; Beznosikov, V.A. The molecular structure and elemental composition of humic substances from Albeluvisols. Chem. Ecol. 2010, 26, 87-95. [CrossRef]

62. Casey, K.A.; Kaspari, S.D.; Skiles, S.M.; Kreutz, K.; Handley, M.J. The spectral and chemical measurement of pollutants on snow near South Pole, Antarctica. J. Geophys. Res. Atmos. 2017, 122, 6592-6610. [CrossRef]

63. Szymański, W. Chemistry and spectroscopic properties of surface horizons of Arctic soils under different types of tundra vegetation-A case study from the Fuglebergsletta coastal plain (SW Spitsbergen). Catena 2017, 156, 325-337. [CrossRef]

64. Stolt, M.H.; Lindbo, D.L. 17 - Soil Organic Matter. In Interpretation of Micromorphological Features of Soils and Regoliths; Stoops, G., Marcelino, V., Mees, F., Eds.; Elsevier: Amsterdam, The Netherlands, 2010; pp. 369-396. [CrossRef]

65. Abakumov, E.V.; Polyakov, V.I.; Orlova, K.S. Podzol development on different aged coastal bars of Lake Ladoga. Vestn. Tomsk. Gos. Univ. Biol. 2019, 48, 6-31. [CrossRef] [PubMed] 